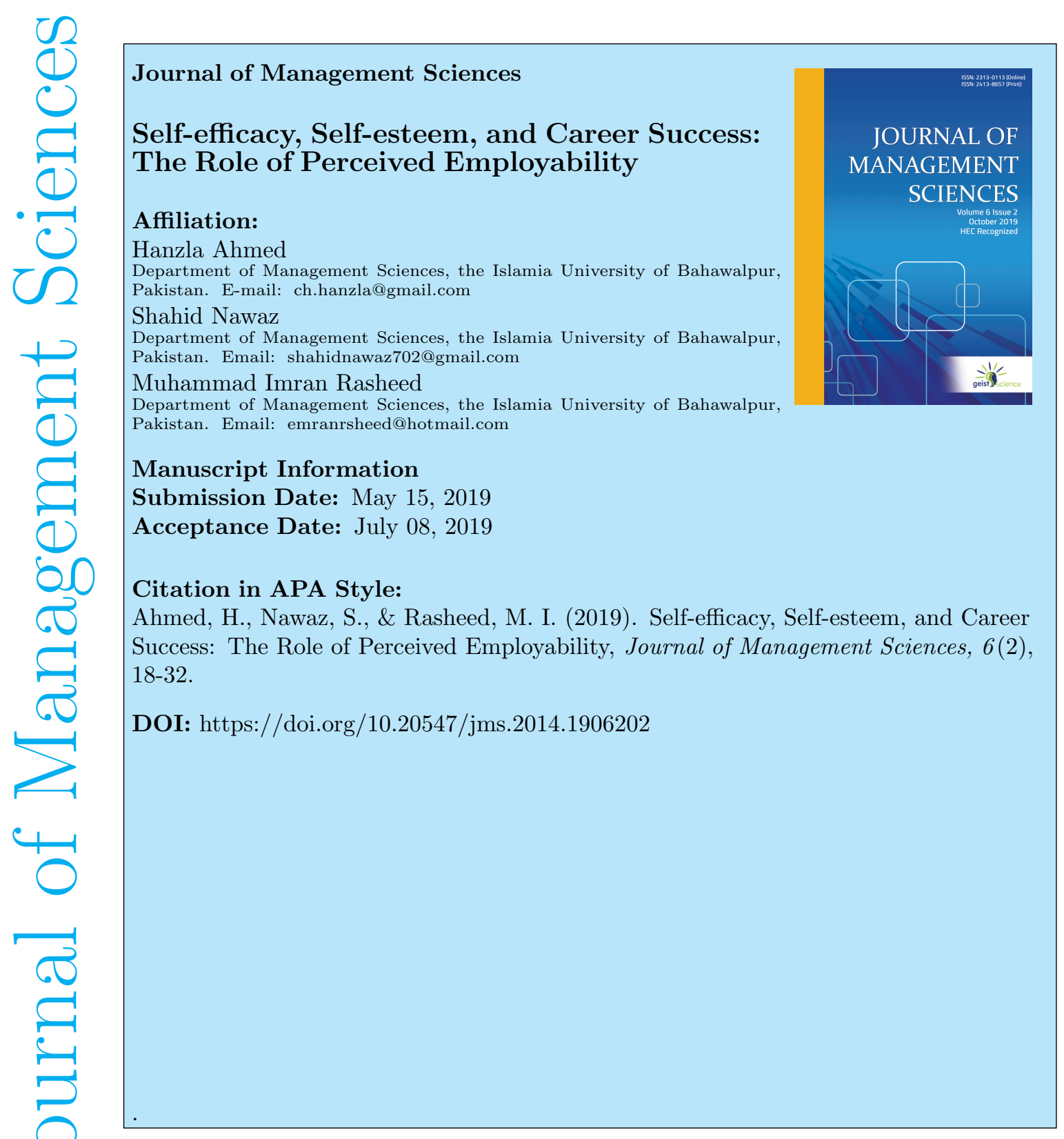




\title{
Self-efficacy, Self-Esteem, and Career Success: The Role of Perceived Employability
}

\author{
Hanzla Ahmed * Shahid Nawaz ${ }^{\dagger} \quad$ Muhammad Imran Rasheed $\ddagger$
}

\begin{abstract}
Perceived employability is the workers' perception of comfortably getting a recruitment opportunity. This paper investigates role breadth self-efficacy and organization based self-esteem as important antecedents of individuals' perceived employability and tests its subsequent relationship with their career success. We collected primary data from 233 respondents working in banking, insurance, and health sectors in southern Punjab Pakistan. The results reveal that individuals' role breadth self-efficacy and organization based self-esteem are positively related to their employability perception which further plays a mediating role in the relationship between self-efficacy and employee career success and self-esteem and employee career success. Important theoretical and practical implications and direction for future research coupled with limitations of the study are discussed.
\end{abstract}

Keywords: Perceived employability, voluntary learning behavior, organization based self-esteem, role breadth self-efficacy, career success.

\section{Introduction}

Career success is taken in terms of gender-oriented role or socio-economic perspectives, individuals have their own meanings of career success on the basis of their experience (Hennequin, 2007). The social perspective has differentiated career success between men and women by creating boundaries around women who cannot follow their careers in every "masculine" sector (Stead \& Bakker, 2010). Recently researchers have observed the job recruitment environment in the context of employment (e.g. boundary-less career; (Arthur, 1994). In the external labor market, finding a job that is similar to the one presently held or a new occupation is relevant to the perceived employability which states to an individual's subjective assessment (Wittekind, Raeder, \& Grote, 2010) always considerable for researchers in Asian as well as European countries (Berntson \& Marklund, 2007; Coetzee \& Harry, 2014). Previous studies mainly focused on both career development, employee selection and recruitment procedure (Wittekind et al., 2010) based on human capital in an organizational setup (Cerrito, Trusty, \& Behun, 2018).

This study observes the experiences of perceived employability of an employee of an organization depend on self-concept theory. Perceived employability includes such

\footnotetext{
* Department of Management Sciences, the Islamia University of Bahawalpur, Pakistan . E-mail: ch.hanzla@gmail.com

${ }^{\dagger}$ Department of Management Sciences, The Islamia University of Bahawalpur, Pakistan. Email: shahidnawaz702@gmail.com

${ }^{\ddagger}$ Department of Management Sciences, The Islamia University of Bahawalpur, Pakistan. Email: emranrsheed@hotmail.com
} 
factors like state constructs or unsatisfied performances (Boeriu, Bravo, Gosselink, \& van Dam, 2004). Self-concept and perceived employability are having a strong connection to each other. Perception of an employee as well as motivation towards its work core ideas of self-concept (Kim, Kim, \& Lee, 2015), is a cognitive ability of the person, which monitor employee interest towards its work (Walumbwa et al., 2011).

The earlier literature is extended by self-concept theories and human capital concerned with career success (CS) which fully deals the perceived employability. The researchers observe that voluntary learning behavior (VLB) and self-concepts strongly linked with perceived employability. Voluntary learning behavior (VLB) is termed as "Continuous, self-directed learning and development that volitionally enhances human capital, such as knowledge, skills, experience, and qualifications" (Avolio, Walumbwa, \& Weber, 2009). Previous studies observed that perceived employability is having a connection between organizational career progress and proper training (Wittekind et al., 2010).

Suggesting and testing the association of employee between self-concepts and career success through perceived employability and considering the moderating role of voluntary learning behavior, this study makes several contributions in the previous literature. For example, there is lack of research, which evaluates how career success and employability are in relation to one another as mostly they are studied in parallel to each other (De Vos, De Hauw, \& Van der Heijden, 2011). Although there is dearth of research on perceived employability from the viewpoint of combined effects of organizational and individual perceptive of competency development (De Vos et al., 2011; Lin, 2015) however, there is very little research which has accompanied to study the relationship between self-concept that is self-esteem and self-efficacy in addition to voluntary learning behavior with career success (Chiesa, Fazi, Guglielmi, \& Mariani, 2018). Second, Prins et al. (2009); Wittekind et al. (2010) have noted that, a major focus of previous studies has been on employability skills but not on perceived employability.

Figure 1

Conceptual model

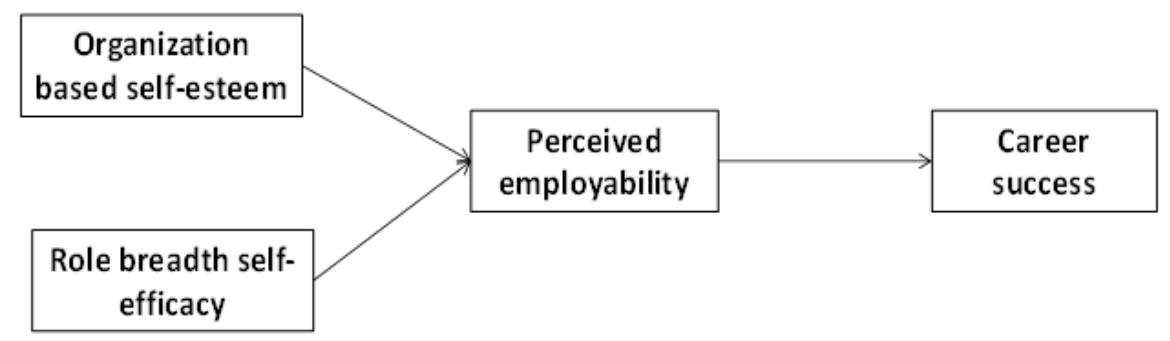

\section{Theory and Hypothesis Development}

Employability is termed as "An individual's chance of a job in the internal and/or external labor market" (Forrier \& Sels, 2003). To maintain employment, Perceived employability is 
the counterpart of the organization to increase performance. According to the definition from Berntson and Marklund (2007) PE deals possibilities of job engagement. The word "possibilities" is used in a sense of structural factors, personal factors, and their relations to each other. Structural features are at the equal of the job and Individual features are tied to the personal qualities network (Griffeth, Steel, Allen, \& Bryan, 2005).

Voluntary learning behavior (VLB) is defined as "The activities in which individuals involved at their own volition, including those outside of company time as well as with an implicit assumption that the learning activity will generate dividends in the current role or in the future time span" (Birdi, Allan, \& Warr, 1997; Edmondson, 1999).

Self-esteem is defined as "A self-evaluation that individuals make and maintain with regard to themselves. Self-esteem states an attitude of consent or disapproval of self; it is a personal evaluation reflecting what people think of themselves as individuals; it indicates the extent to which individuals believe themselves to be capable, reflecting a personal judgment of worthiness." OBSE is defined as the degree to which organizational members believe that they can satisfy their needs by contributing in roles within the context of an organization. People who have high OBSE, have a sense of personal competence as organizational members and a sense of having satisfied needs from their organizational roles in the past. Therefore, organization-based self-esteem (OBSE) mirrors the selfperceived value that individuals have of themselves as organization members substitute within an organizational framework. As an outcome, employees with high organization base self-esteem (OBSE) should perceive themselves as meaningful, important, capable, and worthwhile within their employing organization (Arshadi \& Damiri, 2013).

"Self-efficacy is perceived as a control, which is emerged from research on locus of control" (Rotter, 1966). Self-efficacy refers to subjective judgments of one's capabilities to form and make courses of action to achieve selected goals, and he sought to measure its generality, level, and strength across activities and contexts (Bandura, 1986). Self-efficacy denotes to its dependence on the difficulty of a specific task, such as spelling words of increasing difficulty; overview pertains to the transferability of self-efficacy views across activities, such as from algebra to statistics; the strength of perceived efficacy is measured by the amount of one's certainty about performing a given task. Role breadth self-efficacy (RBSE) is a judgment about aptitude across a specific set of tasks that is also amenable to change. Parker (1998) presented that RBSE will separate both self-esteem and proactive personality. According to Judge, Higgins, Thoresen, and Barrick (1999); Law, Henk, Lennox, and Hodson (1982), career success is the positive psychological or work-related achievements or outcomes one has added as a result of one's work practices. As Jaskolka, Beyer, and Trice (1985) noted, career success is the judgments of career depend on who does the judging. Career success is determined on the basis of relatively objective and visible criteria as well as judged by others (Jaskolka et al., 1985). Researchers frequently state to this type of career success as an objective success because it can be measured by observable exoteric metrics such as a number of promotions and salary packages (Gattiker \& Larwood, 1988; Judge \& Welbourne, 1994). 


\section{Organization Based Self-Esteem and Perceived Employability}

The idea of employability has by and large been caught by the perspective of arrangement creators and bosses whose fundamental accentuation was on the supply side of capacity in the work showcase. Distinctive specialists depict apparent employability as the aptitudes, capacities, demeanors and individual qualities that an individual must need to show signs of improving business opportunity.

Dahlstrom and Bichsel (2014) explored the relationship of employability with pragmatic learning in the College situated in Body in (2011-2012). He contends that such learning relies upon two basics that is the expertise of work and ensuing investigation to properly get a handle on that understanding and to relate it to future exertion. Zhiwen and van der Heijden (2008) inspect the association of the impression of employability with the present changes in vocation advancement.

Organization based self-esteem (OBSE) mirrors the self-assessment of individual ability and feeling of worth as an individual from an association (Norris, Leighton, \& DeSimone, 1989). OBSE of a representative is in every case high who has an abnormal state of sees oneself as significant, essential, capable, and profitable inside the association, and the person holds the conviction, "I am a critical piece of this spot" (Norris et al., 1989). We propose that there is a positive relationship between seen employability and association based confidence (OBSE). This affiliation might be clarified by the social correlation technique (Taylor \& Lobel, 1989), which characterizes the certain and express propensities to contrast oneself as well as other people and with reference gatherings to get data about oneself to make precise self-assessments of one's abilities and conclusions (Gibbons \& Buunk, 1999).

$H_{1}$ : There is a positive relationship between organization based self-esteem on perceived employability.

\section{Role Breadth Self-Efficacy and Perceived Employability}

RBSE is characterized as "The degree to which individuals feel certain and feel that they can do a more extensive and proactive job, past customary endorsed specialized prerequisites" (Parker, 1998). Representatives with high RBSE show an inclination to see their activity job all the more comprehensively and direct a more extensive scope of errands inside an association than workers with lower RBSE (Axtell \& Parker, 2003). As per the examination general self-viability (SE) and employability (PE) are diverse yet related wonder (Berntson, 2008). ity.

$\mathrm{H}_{2}$ : There is a positive relationship between role breadth self-efficacy on perceived employabil- 


\section{Perceived Employability and Career Success}

A huge result of employability is profession achievement. Vocation achievement is characterized as the "Amassed positive work and mental results coming about because of one's work encounters" (Seibert \& Kraimer, 2001). Profession achievement (CS) can be operationalized as either objective or emotional. Target profession achievement (CS) is quantifiable and incorporates compensation, execution, advancement history, and nature of work in an association. Van Maanen and Schein (1977) depicts emotional vocation accomplishment as "The person's inner trepidation and assessment of his or her vocation, over any measurements that are vital to the individual". These emotional results incorporate work-life balance, reason, feeling of significance and excellencies from their work (Heslin, 2005).

Outer elements incorporate factors outside of yourself that impact your employability and blue-collar limit. Outside components incorporate geographic zone, monetary conditions, the industry you have picked, and the interest for specific positions by industry or employment work. Most outer elements impact both pay and employability. Some portion of this phase of the procedure includes choosing what industry or employment work you will concentrate on. This combined with the outside elements will decide your employability and working class limit (Heslin, 2005) prior investigations in the area of the profession the executives and preparing and improvement propose the likelihood of direct relationship with vocation achievement. This presumption pursues from the supported versatility model of vocation achievement D. P. (Rosenbaum \& Lurigio, 1994; Teeling et al., 2005) which expresses that (taking an interest in) hierarchical activities like profession backing and aptitude advancement openings will be decidedly identified with profession achievement. In help of this, Burke, McKeen, and McKenna (1994) found that workers' interest in competency improvement was legitimately identified with their view of future profession prospects (Burke et al., 1994), while (De Vos, Dewettinck, \& Buyens, 2009) found an immediate relationship between saw boss help for vocation advancement and vocation fulfillment.

Perceived employability (PE) will be emphatically related to both profession results. Self-saw employability is characterized in such sense, considered as human capital and human capital variable. The hypothesis suggests that putting resources into individual aptitudes should prompt more noteworthy incentive in the commercial center (Becker, DeGroot, \& Marschak, 1964). The challenge versatility model of CS frames on this proof by expressing that, in a more extensive sense, human capital components like abilities will be emphatically connected to vocation achievement $(\mathrm{Ng}, 2005)$. However, to date, exploratory research looking at this affiliation is rare. Eby, Butts, and Lockwood (2003) watched a positive relationship between vocation fulfillment and representatives' ability expanding on an apparent attractiveness. Seen attractiveness is characterized as convictions that one is profitable to the current or to different businesses (Eby et al., 2003). In the present profession setting, described by vulnerability and eccentrics, the degree to which people accept to be viewed as attractive by their present or future businesses is an important marker of abstract vocation achievement (CS) (De Vos \& Soens, 2008; Eby et al., 2003). Attractiveness is thoughtfully unique in relation to employability in that the last 
incorporates the worker's capabilities (regarding learning, aptitudes, and capacities), for example, secure or make new work, their capability to satisfy, if vital, while attractiveness talks about to a positive vocation result of this potential, for example the bits of knowledge concerning one's additional incentive at them work showcase.

$H_{3}$ : There is a positive relationship between perceived employability and career success.

\section{The Mediating Job of Perceived Employability}

A representative's ramifications significant from examination with coworkers might be connected to the worker's apparent employability. On the off chance that faculty of an association see themselves as profitable contrasted with different individuals from the association, they may presume that they are likewise better than the normal individual outside the association: Perceived employability directions incorporate quality at work, confidence, work fulfillment, self-adequacy, and occupation weariness.

Dimensions of learning, knowledge and representative aptitudes are connected to apparent employability (Wittekind et al., 2010). To increment workers' trust in their skill as occupation searchers, human capital itself may not be a satisfactory standard to assess representatives' apparent employability. Vocation achievement is a worry of both the individual and association, in that the accomplishment of an individual can at last add to the association's prosperity (Judge et al., 1999). This investigation watches CS and OBSE which are self-ideas worked inside a worker's present association. In the outside work showcase, a laborer may take a basic sign from the data about the self inside the inward work advertise.

The idea of RBSE was first exhibited through Bandura in the time of 1970s. He portrays job expansiveness self-adequacy an assessment the individual will viably execute a recognition that is obligatory in producing unmistakable outcomes. RBSE of the Employees is in every case high who are normal mindful that they have options for vocations in the activity advertise given the number of assignments and jobs they are certain about performing in their professional achievement. An investigation introduced that general self-adequacy and employability are distinctive however connected marvels (Cuyper, Bernhard-Oettel, Berntson, Witte, \& Alarco, 2008).

$H_{4}$ : Perceived employability mediates the relationship between organization based self-esteem and career success.

$H_{5}$ : Perceived employability mediates the relationship between role breadth self-efficacy and career success. 


\section{Methodology}

\section{Participants and Procedure}

We conducted a survey in southern Punjab Pakistan for collecting primary data to empirically test the model we theorized. One of the authors personally visited organizations that belong to banking, insurance, and health industries and distributed 450 questionnaires. Out of the distributed questionnaires, 278 were returned (61.78\% response rate). We excluded 45 questionnaires as they were either incomplete or were unable to be used in analyses. Out of 233 final respondents, 53.6\% were males, $42 \%$ were in the age group of 30 to 40 years, $63 \%$ were married, and $43.1 \%$ were having a graduation degree.

\section{Measures}

\section{Organization Based Self-Esteem}

The 5-item scale of OBSE from Griffeth et al. (2005) was used to assess our respondents' organization based self-esteem. This scale was designed on 5 point Likert scale ranging from 1 = strongly disagree to $5=$ strongly agree. Sample items are for example, "I count around here" and "I am valuable around here." The Cronbach's alpha for this scale in our study was 0.83 .

\section{Role Based Self-Efficacy}

We used the 6-item scale of RBSE from Parker (1998) to assess our respondents' role based self-efficacy. This scale was designed on a 5 point likert scale ranging from $1=$ strongly disagree to $5=$ strongly agree. Sample items are for example, "representing your work area in meetings with senior management" and "making suggestions to management about ways to improve the function of your section." The Cronbach's alpha for this scale in our study was 0.81 .

\section{Perceived Employability}

The 3-item scale of perceived employability from was adapted from Wittekind et al. (2010) was used to assess perceived employability of our respondents. This scale was designed on the 5 point Likert scale ranging from $1=$ strongly disagree to $5=$ strongly agree. Sample items are for example, "I am confident that I would find another job if I started searching" and "In case I'm dismissed, I will immediately find a job of equal value." The Cronbach's alpha for this scale in our study was 0.94 .

\section{Career Success}

We used the 24-item subjective career success scale (SCSS) from Shockley, Ureksoy, Rodopman, Poteat, and Dullaghan (2016) to assess career success perceptions of our respondents. This scale was designed on 5 point Likert scale ranging from $1=$ strongly disagree 
to 5 = strongly agree. Sample items are for example, "Considering my career as a whole, I have been recognized for my contributions", and "Considering my career as a whole, I think my work has been meaningful". The Cronbach's alpha for this scale in our study was 0.78 .

\section{Analyses and Results}

We utilized SPSS PROCESS macro (Preacher \& Hayes, 2008; Hayes, 2017; Sattar, Rasheed, Khan, Tariq, \& Iqbal, 2017) to test the hypotheses of our study. Before analyses we mean centered all the continuous measures as it is recommended by Aiken, West, and Reno (1991).

\section{Descriptive Statistics}

Table 1 shows mean, standard deviation, and inter-correlation among the constructs used in this study. Organization based self-esteem $(\mathrm{r}=.42, \mathrm{p}=.01)$ and role breadth self-efficacy $(\mathrm{r}=.38, \mathrm{p}=.001)$, are positively associated with customer satisfaction. Similarly, organization based self-esteem $(\mathrm{r}=.30, \mathrm{p}=.01)$ and role breadth self-efficacy $(\mathrm{r}=.34, \mathrm{p}=.01)$, are positively associated with electronic perceived employability. In addition, perceived employability is positively associated with career success $(\mathrm{r}=.52, \mathrm{p}=.01)$.

\begin{tabular}{|c|c|c|c|c|c|c|}
\hline Variables & Mean & S.D. & 1 & 2 & 3 & 4 \\
\hline Organization based self-esteem & 0.419 & 0.494 & 0.83 & & & \\
\hline Role breadth self-efficacy & 2.247 & 1.199 & 0.006 & 0.81 & & \\
\hline Perceived employability & 2.398 & 0.991 & $.306^{* *}$ & $.341^{* *}$ & 0.94 & \\
\hline Career success & 3.537 & 0.587 & $.42^{* *}$ & $.38^{* * *}$ & $.52^{* *}$ & 0.78 \\
\hline
\end{tabular}

\section{Mediation Analysis}

For testing our full hypothesized theoretical research model, we applied Model 4 of SPSS PROCESS macro. The results of the PROCESS output are reported in Table 2 and Table 3. These results have given support to our preliminary analyses as organization based self esteem $(B=.63, t=12.62, p=.001$, Table 2$)$ and role breadth self-efficacy $(B=.65, t$ $=13.45, \mathrm{p}=.001$, Table 3 ) show positive associations with perceived employability which supports our H1a and $\mathrm{H} 2 \mathrm{a}$. Results further show that perceived employability $(\mathrm{B}=.83, \mathrm{t}$ $=16.6, \mathrm{p}=.001$ ) has a positive association with employee career success which supports our H3.

For mediation analysis, we performed Sobel tests using the bootstrap procedure with $95 \%$ bias correlated confidence intervals (CIs). The indirect relationship between organization based self-esteem and career success (Sobel $\mathrm{z}=8.54, \mathrm{p}<.001$, Table2) and role breadth self-efficacy and career success (Sobel $z=8.51, p<.001$, Table 3 ) both are significant. In addition, bootstrapped CIs do not contain zero (organization based self-esteem 
.21 to .53 , Table 2 ; role breadth self-efficacy .21 to .45 , Table 3 ). These results provide an evidence that perceived employability is a significant mediator in the relationships between (i) organization based self-esteem and career success and (ii) role breadth self-efficacy and career success. These results provide support for our hypotheses $\mathrm{H} 4$ and $\mathrm{H} 5$.

Table 2

Results of Mediation Analysis

\begin{tabular}{|c|c|c|c|c|c|c|c|c|}
\hline \multirow[b]{2}{*}{ Independent Variable } & \multicolumn{4}{|c|}{$\begin{array}{c}\text { Mediator } \\
\text { Perceived employability }\end{array}$} & \multicolumn{4}{|c|}{$\begin{array}{c}\text { Dependent Variable } \\
\text { Career Success }\end{array}$} \\
\hline & B & SE & $t$ & $\begin{array}{c}R^{2} \\
0.271\end{array}$ & B & SE & $t$ & $\begin{array}{c}R^{2} \\
0.532\end{array}$ \\
\hline Constant & 1.65 & 0.19 & $8.68^{* * *}$ & & 0.69 & 0.2 & $3.45^{* *}$ & \\
\hline Organization based self-esteem & 0.631 & 0.05 & $12.62^{* * *}$ & & 0.15 & 0.06 & $2.50^{* *}$ & \\
\hline Perceived employability & - & - & - & & 0.83 & 0.05 & $16.6^{* * *}$ & \\
\hline Indirect effects & & & & & Effect & SE & LLCI & ULCI \\
\hline Organization based self-esteem to career success & & & & & $\begin{array}{c}0.37 \\
\text { Effect }\end{array}$ & $\begin{array}{c}0.045 \\
\text { SE }\end{array}$ & $\begin{array}{c}0.21 \\
\mathbf{z}\end{array}$ & 0.53 \\
\hline Normal theory test & & & & & 0.371 & 0.041 & $8.54^{* * *}$ & \\
\hline
\end{tabular}

Table 3

Results of Mediation Analysis

\begin{tabular}{|c|c|c|c|c|c|c|c|c|}
\hline \multirow[b]{2}{*}{ Independent Variable } & \multicolumn{4}{|c|}{$\begin{array}{c}\text { Mediator } \\
\text { Perceived employability }\end{array}$} & \multicolumn{4}{|c|}{$\begin{array}{l}\text { Dependent Variable } \\
\text { Career Success }\end{array}$} \\
\hline & B & SE & $t$ & $\begin{array}{c}R^{2} \\
0.37\end{array}$ & B & SE & $t$ & $\begin{array}{c}R^{2} \\
0.51\end{array}$ \\
\hline Constant & 1.81 & 0.21 & $8.62 * * *$ & & 0.65 & 0.19 & $3.42^{* * *}$ & \\
\hline Role Breadth self-efficacy & 0.65 & 0.05 & $13.45^{* * *}$ & & 0.13 & 0.05 & $2.60 * *$ & \\
\hline Perceived employability & - & - & - & & 0.65 & 0.05 & $13.01^{* * *}$ & \\
\hline Indirect effects & & & & & Effect & SE & LLCI & ULCI \\
\hline \multirow[t]{2}{*}{ Organization based self-esteem to career success } & & & & & 0.31 & 0.05 & 0.21 & 0.45 \\
\hline & & & & & Effect & SE & $\mathbf{z}$ & \\
\hline Normal theory test & & & & & 0.36 & 0.05 & 8.51 & \\
\hline
\end{tabular}

\section{Discussion}

This study was conducted in order to understand the relationship between a person's selfconcepts and his career success by exploring the role of perceived employability in Pakistan. The results of our study have confirmed that individuals' role breadth self-efficacy and organization based self-esteem are positively associated with their career success in organizations. Results have also confirmed the mediating role of perceived employability in the relationships between individuals' self-concept and career success as our findings show that individuals' role breadth self-efficacy and organization based self-esteem are positively associated with their career success through perceived employability. The investigation of perceived employability as a mediating variable in our model is a unique 
finding which contributes to eh literature in understanding the reason that why individuals' positive self-concepts such as organization based self-esteem and role breadth selfefficacy are related to their career success. Our results have confirmed previous research findings, for instance, Guan et al. (2016) found that there is a positive relationship between employees' decision making self-efficacy and their career success. Similarly, Hirschi, Herrmann, and Keller (2015) found a relationship between occupational self-efficacy and career success. Kim et al. (2015) investigated employee self-concepts and found that there is a positive relationship between individuals' self-concepts and their perceived employability. Our study extends these past findings and suggests that there is a positive relationship between individuals' role breadth self-efficacy and their career success and individuals' perceived employability plays a mediating role in this relationship.

Our results further suggest that there is a positive association between individuals' organization based self-esteem and their career success and this relationship is mediated by the perceived employability. This is an interesting finding that highlights the role of organization based self-esteem so as to know the career success of individuals in organizations. The mediating results explore the mediating role of perceived employability and suggest that the relationship between individuals' organization based self-esteem and career success is explained by their perceived employability. These findings are supported by previous research as Yang, Zhang, Kwan, and Chen (2018) found a positive relationship between organization based self-esteem and quality of life. Neff, Sonnentag, Niessen, and Unger (2015) found that organization based self-esteem is positively associated with the performance of employees. Similarly, Kim et al. (2015) investigated employee selfconcepts and found that there is a positive relationship between individuals' organization based self-esteem and perceived employability. Our findings have extended this past research as it suggests that individuals' organization based self-esteem is positively associated with their career success and this relationship is explained by the mediating role of perceived employability. A potential explanation to our results is that individuals' selfconcepts such as organization based self-esteem and role breadth self-efficacy are positively associated with perceived employability which in turn is positively associated with their career success.

\section{Practical Implications}

Our study has important practical implications for individuals, managers, organizations, and human resource practitioners and vocational psychologists. Our findings have explored the role of individuals' self-concept with regard to its positive association with career success. Individuals' should, therefore, try to enhance their role breadth selfefficacy and organization based self-esteem in order to gain more career success. Managers and organizations can also work to find ways that can enhance their employees' self-concepts which in turn are related to higher perceived self-efficacy and more career success. They can arrange a specific type of training and workshops to boost their employees' role breadth self-efficacy and organization based self-esteem like self-concepts. Vocational psychologists and human resource practitioners should also give a due importance to the self-concepts of individuals while designing courses aimed at enhancing their 
positive perceptions of employability and career success.

\section{Limitations and Directions for Future Research}

Our study although has been conducted very carefully and by putting maximum effort still has some limitations. For example, our data is cross-sectional in nature that is all the data was collected at one time which may cause a problem of common method variance. Tehseen, Ramayah, and Sajilan (2017) suggested that the prevalence of CMV can affect research findings in social sciences if not controlled. We although have ensured to reduce the chances of CMV by taking some procedural remedies such as anonymity and confidentiality of respondents but future research can benefit more from our theorized model by conducting longitudinal research. Moreover, we explored perceived employability as a mediating mechanism in the relationship between individuals' self-concepts and career success. Although perceived employability is an important variable needed to be studied especially in the context of a developing country such as Pakistan (Zafar, Farooq, \& Quddoos, 2017) but we believe that there may also exist some alternative explanations. Moreover, we explored one mediating mechanism that is perceived employability in the relationship between individuals' self-concepts and career success but we believe that there may exist some alternative explanations. Future researchers can, therefore, investigate some alternative variables which explain the underlying psychological mechanism in the relationship between individuals' self-concepts and their career success. Future researchers can also theorize and test a boundary condition to the relationships conceptualized in our study, thus investigating a moderating variable in our model can be of high value. In addition, our respondents belong to a single country that is Pakistan which reduces the generalizability of our findings. Future research should, therefore, be conducted in other countries and regions so as to understand the cultural impact on our model. 


\section{References}

Aiken, L. S., West, S. G., \& Reno, R. R. (1991). Multiple regression: Testing and interpreting interactions. USA: Sage.

Arshadi, N., \& Damiri, H. (2013). The relationship of job stress with turnover intention and job performance: Moderating role of OBSE. Procedia-Social and Behavioral Sciences, 84, 706-710.

Arthur, W. B. (1994). Increasing returns and path dependence in the economy. University of Michigan Press.

Avolio, B. J., Walumbwa, F. O., \& Weber, T. J. (2009). Leadership: Current theories, research, and future directions. Annual Review of Psychology, 60, 421-449.

Axtell, C. M., \& Parker, S. K. (2003). Promoting role breadth self-efficacy through involvement, work redesign and training. Human Relations, 56(1), 113-131.

Bandura, A. (1986). Fearful expectations and avoidant actions as coeffects of perceived self-inefficacy. , 41(12). doi: 10.1037/0003-066X.41.12.1389

Becker, G. M., DeGroot, M. H., \& Marschak, J. (1964). Measuring utility by a singleresponse sequential method. Behavioral Science, 9(3), 226-232.

Berntson, E. (2008). Employability perceptions: Nature, determinants, and implications for health and well-being (Unpublished doctoral dissertation). Psykologiska institutionen.

Berntson, E., \& Marklund, S. (2007). The relationship between perceived employability and subsequent health. Work E Stress, 21(3), 279-292.

Birdi, K., Allan, C., \& Warr, P. (1997). Correlates and perceived outcomes of 4 types of employee development activity. Journal of Applied Psychology, 82(6), 845-857.

Boeriu, C. G., Bravo, D., Gosselink, R. J., \& van Dam, J. E. (2004). Characterisation of structure-dependent functional properties of lignin with infrared spectroscopy. Industrial Crops and Products, 20(2), 205-218.

Burke, R. J., McKeen, C. A., \& McKenna, C. (1994). Benefits of mentoring in organizations: The mentor's perspective. Journal of Managerial Psychology, 9(3), 23-32.

Cerrito, J. A., Trusty, J., \& Behun, R. J. (2018). Comparing web-based and traditional career interventions with elementary students: An experimental study. The Career Development Quarterly, 66(4), 286-299.

Chiesa, R., Fazi, L., Guglielmi, D., \& Mariani, M. (2018). Enhancing substainability: Psychological capital, perceived employability, and job insecurity in different work contract conditions. Sustainability, 10(7), 2475-2485.

Coetzee, M., \& Harry, N. (2014). Emotional intelligence as a predictor of employees' career adaptability. Journal of Vocational Behavior, 84(1), 90-97.

Cuyper, N. D., Bernhard-Oettel, C., Berntson, E., Witte, H. D., \& Alarco, B. (2008). Employability and employees' well-being: Mediation by job insecurity. Applied Psychology, 57(3), 488-509.

Dahlstrom, E., \& Bichsel, J. (2014). Ecar study of undergraduate students and information technology, 2014. Educause. Retrieved from https://eric.ed.gov/ ?id=ED 564481 
De Vos, A., De Hauw, S., \& Van der Heijden, B. I. (2011). Competency development and career success: The mediating role of employability. Journal of Vocational Behavior, $79(2), 438-447$.

De Vos, A., Dewettinck, K., \& Buyens, D. (2009). The professional career on the right track: A study on the interaction between career self-management and organizational career management in explaining employee outcomes. European Journal of Work and Organizational Psychology, 18(1), 55-80.

De Vos, A., \& Soens, N. (2008). Protean attitude and career success: The mediating role of self-management. Journal of Vocational Behavior, 73(3), 449-456.

Eby, L. T., Butts, M., \& Lockwood, A. (2003). Predictors of success in the era of the boundaryless career. Journal of Organizational Behavior: The International Journal of Industrial, Occupational and Organizational Psychology and Behavior, 24(6), 689-708.

Edmondson, A. (1999). Psychological safety and learning behavior in work teams. Administrative Science Quarterly, 44(2), 350-383.

Forrier, A., \& Sels, L. (2003). Temporary employment and employability: Training opportunities and efforts of temporary and permanent employees in belgium. Work, Employment and Society, 17(4), 641-666.

Gattiker, U. E., \& Larwood, L. (1988). Predictors for managers' career mobility, success, and satisfaction. Human Relations, 41(8), 569-591.

Gibbons, F. X., \& Buunk, B. P. (1999). Individual differences in social comparison: Development of a scale of social comparison orientation. Journal of Personality and Social Psychology, 76(1), 129-142.

Griffeth, R. W., Steel, R. P., Allen, D. G., \& Bryan, N. (2005). The development of a multidimensional measure of job market cognitions: The employment opportunity index (EOI). Journal of Applied Psychology, 90(2), 335-349.

Guan, P., Capezio, A., Restubog, S. L. D., Read, S., Lajom, J. A. L., \& Li, M. (2016). The role of traditionality in the relationships among parental support, career decisionmaking self-efficacy and career adaptability. Journal of Vocational Behavior, 94, 114123.

Hayes, A. F. (2017). Introduction to mediation, moderation, and conditional process analysis: A regression-based approach. New York: Guilford Publications.

Hennequin, E. (2007). What "career success" means to blue-collar workers. Career Development International, 12(6), 565-581.

Heslin, P. A. (2005). Conceptualizing and evaluating career success. Journal of Organizational Behavior: The International Journal of Industrial, Occupational and Organizational Psychology and Behavior, 26(2), 113-136.

Hirschi, A., Herrmann, A., \& Keller, A. C. (2015). Career adaptivity, adaptability, and adapting: A conceptual and empirical investigation. Journal of Vocational Behavior, 87, 1-10.

Jaskolka, G., Beyer, J. M., \& Trice, H. M. (1985). Measuring and predicting managerial success. Journal of Vocational Behavior, 26(2), 189-205.

Judge, T. A., Higgins, C. A., Thoresen, C. J., \& Barrick, M. R. (1999). The big five personality traits, general mental ability, and career success across the life span. Personnel Psychology, 52(3), 621-652. 
Judge, T. A., \& Welbourne, T. M. (1994). A confirmatory investigation of the dimensionality of the pay satisfaction questionnaire. Journal of Applied Psychology, 79(3), 461-466.

Kim, S., Kim, H., \& Lee, J. (2015). Employee self-concepts, voluntary learning behavior, and perceived employability. Journal of Managerial Psychology, 30(3), 264-279.

Law, M., Henk, J., Lennox, S., \& Hodson, M. (1982). Value of radiotherapy for tumour on the bronchial stump after resection for bronchial carcinoma. Thorax, 37(7), 496-499.

Lin, Y.-c. (2015). Are you a protean talent? The influence of protean career attitude, learning-goal orientation and perceived internal and external employability. Career Development International, 20(7), 753-772.

Neff, A., Sonnentag, S., Niessen, C., \& Unger, D. (2015). The crossover of self-esteem: A longitudinal perspective. European Journal of Work and Organizational Psychology, 24(2), 197-210.

$\mathrm{Ng}$, K. P. (2005). Interpreting China's military power: Doctrine makes readiness. UK: Routledge.

Norris, M. C., Leighton, B. L., \& DeSimone, C. A. (1989). Needle bevel direction and headache after inadvertent dural puncture. Anesthesiology, 70(5), 729-731.

Parker, S. K. (1998). Enhancing role breadth self-efficacy: The roles of job enrichment and other organizational interventions. Journal of Applied Psychology, 83(6), 835-852.

Preacher, K. J., \& Hayes, A. F. (2008). Asymptotic and resampling strategies for assessing and comparing indirect effects in multiple mediator models. Behavior Research Methods, 40(3), 879-891.

Prins, J., Van Der Heijden, F., Hoekstra-Weebers, J., Bakker, A., Van de Wiel, H., Jacobs, B., \& Gazendam-Donofrio, S. M. (2009). Burnout, engagement and resident physicians' self-reported errors. Psychology, Health \& Medicine, 14(6), 654-666.

Rosenbaum, D. P., \& Lurigio, A. J. (1994). An inside look at community policing reform: Definitions, organizational changes, and evaluation findings. Crime $\mathcal{E}$ Delinquency, 40(3), 299-314.

Rotter, J. B. (1966). Generalized expectancies for internal versus external control of reinforcement. Psychological Monographs: General and Applied, 80(1), 1-27.

Sattar, M. A., Rasheed, M. I., Khan, I. U., Tariq, H., \& Iqbal, J. (2017). Why adaptable individuals perform better: The role of orientation to happiness. Australian Journal of Career Development, 26(3), 134-141.

Seibert, S. E., \& Kraimer, M. L. (2001). The five-factor model of personality and career success. Journal of Vocational Behavior, 58(1), 1-21.

Shockley, K. M., Ureksoy, H., Rodopman, O. B., Poteat, L. F., \& Dullaghan, T. R. (2016). Development of a new scale to measure subjective career success: A mixed-methods study. Journal of Organizational Behavior, 37(1), 128-153.

Stead, G. B., \& Bakker, T. M. (2010). Self in career theory and counselling: A discourse analysis perspective. British Journal of Guidance \& Counselling, 38(1), 45-60.

Taylor, S. E., \& Lobel, M. (1989). Social comparison activity under threat: Downward evaluation and upward contacts. Psychological Review, 96(4), 569-575.

Teeling, E. C., Springer, M. S., Madsen, O., Bates, P., O’brien, S. J., \& Murphy, W. J. (2005). A molecular phylogeny for bats illuminates biogeography and the fossil record. Sci- 
ence, 307(5709), 580-584.

Tehseen, S., Ramayah, T., \& Sajilan, S. (2017). Testing and controlling for common method variance: A review of available methods. Journal of Management Sciences, 4(2), 142168.

Van Maanen, J. E., \& Schein, E. H. (1977). Toward a theory of organizational socialization. Retrieved from https://dspace.mit.edu/bitstream/handle/ 1721.1/1934/ ? sequence=1

Walumbwa, F. O., Mayer, D. M., Wang, P., Wang, H., Workman, K., \& Christensen, A. L. (2011). Linking ethical leadership to employee performance: The roles of leadermember exchange, self-efficacy, and organizational identification. Organizational Behavior and Human Decision Processes, 115(2), 204-213.

Wittekind, A., Raeder, S., \& Grote, G. (2010). A longitudinal study of determinants of perceived employability. Journal of Organizational Behavior, 31(4), 566-586.

Yang, Z., Zhang, H., Kwan, H. K., \& Chen, S. (2018). Crossover effects of servant leadership and job social support on employee spouses: The mediating role of employee organization-based self-esteem. Journal of Business Ethics, 147(3), 595-604.

Zafar, J., Farooq, M., \& Quddoos, M. U. (2017). The relationship between protean career orientation and perceived employability: A study of private sector academics of Pakistan. Journal of Management Sciences, 4(2), 133-145.

Zhiwen, G., \& van der Heijden, B. I. (2008). Employability enhancement of business graduates in China: Reacting upon challenges of globalization and labour market demands. Education+ Training, 50(4), 289-304. 